\title{
Penney's evidence on British nuclear bombs
}

THE hearings of the Australian Royal Commission in London may not yet have got to the bottom of what happened during the British nuclear weapons tests in Australia, but they have told the British more about the politics of their bombs. Last week it was revealed that Sir Winston Churchill had refused in the 1950 s to share British nuclear secrets with the United States, insisting on separate bomb tests at a new site in Australia.

Lord Penney (75), then Dr William Penney, in charge of Britain's test programme and the first witness for the British government, told the inquiry of a "highly restrictive" offer made in September 1951 by the United States as a condition for Britain using the Nevada testsite; all the material in the bomb and the physics involved would have had to be disclosed. Lord Penney said that he had been willing to accept the conditions to rekindle Anglo-US collaboration, but that Churchill refused.

As the first director of the Atomic Weapons Research Establishment (AWRE), Penney was under considerable pressure from the military to produce an "operational" bomb and started plans to develop high-yield weapons. Lord Penney said last week that the Australian government and Australian and British public were kept in the dark about the actual sizes of the bombs tested. The second British test explosion in the MOSAIC series, on 19 June 1956, was described by the British government as being of a size similar to the first test, that is $15 \mathrm{kT}$, but was revealed to have been a 60-kT explosion only in March 1984. A 1957 AWRE report on the tests even suggests that the yield could have been as much as $98 \mathrm{kT}$, but Penney said last week he mistrusted that figure. He explained that the most accurate measure of the bomb's yield would come from radiochemical analysis of debris from close to ground zero, revealing the amount of plutonium actually exploded, but the report detailing results from this method of yield detection has not yet been made available by the British government since it is "weapon-design sensitive".

Mr Justice McClelland was anxious to clear up a question facing the inquiry on Monday. This concerned confusion over documents released by the British government which were marked "obsolete". Mr McClelland said that he was reminded of the Watergate trial at which reports had been officially marked "inoperative". $\mathrm{Mr}$ Robin Auld QC spoke for the British government and assured the commission that this was simply an indication that subsequent reports exist which take into account current knowledge, rather than a revision of the actual material of the document.
Lord Penney admitted that efforts to determine the level of ground contamination after the BUFFALO tests of late 1956 were not entirely satisfactory. The commission's counsel, Mr Peter McClellan, inferred from this that similar problems were likely to have been encountered at the TOTEM tests, some three years earlier, after which "black mists" were seen in central Australia. Lord Penney said, however, that he had not even heard of the mists until he read about them in the British press two years ago. He also said that he had no knowledge of concern about the cloud from the MOSAIC 2 test.

Penney did however agree that forecast trajectories of clouds from the BUFFALO series were found to be drastically off course. One trajectory, predicted to pass north of Brisbane, was observed just north of Sydney - " "not very close to Brisbane at all" as Mr McClellan put it. The cloud from the last test in the series was also predicted to travel north of Brisbane, but it was actually found to pass over most of the Australian mainland. Penney insisted, however, that the doses received by people would have been too low to cause concern

On the safety of aborigines, Mr Geoff Eames, representing ten aboriginal organizations, challenged Penney with a 1956 AWRE report stating that "for aborigines in the tribal state, virtually naked and in bare feet ... an acceptable level (of radiation) was only to be found at 240 miles from ground zero"'. Lord Penney, who had set a distance of 100 miles as being acceptable, said that he did not recall this recommendation, but that he knew of aborigines living between 200 and 300 miles from ground zero. Mr Eames told the inquiry of homesteads as close as 107 , 120 and 160 miles from the Emu site and 175,200 and 210 miles from Maralinga.

On previous evidence that aborigines were found living in the Marcoo crater after the BUFFALO series, Penney said he could not confirm or deny these reports. He said there had been an agreement between the British and the Australians that, when there were no British at the test site, site-security was Australian responsibility.

He denied that he regarded the Australians at the tests as "radiologically expendable", saying that if he had heard of aborigines living in the crater, his first question would have been "what dose have they got?". But he acknowledged that although he had advised that site areas should be marked as dangerous, by notices in various languages and "scary signs", he was certain that this had been done only after the HURRICANE tests in 1952, but not subsequently. Illiteracy seems not to have been taken into account. Penney also said that he had no recollection that soldiers were threatened with courts- martial if any of them told the outside world that aborigines had been found in the crater, as alleged in previous evidence to the inquiry.

Throughout the British tests in Australia, the International Commission for Radiological Protection (ICRP) safety guidelines were followed, said Penney, but only after the Windscale fire in 1957 were the dangers of radiation fully appreciated. That sparked off a "revolution in health physics". Penney explained that, because some tasks involved radiation greater than the ICRP recommendations, a radiological protection branch was formed to be responsible for supervising the radiological health and safety of British weapons work.

Radiation doses were measured by film badges. The inquiry has learned that servicemen were unwilling to follow the advice to wear these close to their genitals, and that a report of experiments in 1956 showed that the result might be to underestimate exposure by 40 per cent. But Lord Penney said he could not remember revising the regulations on dose levels in the light of this report.

One of the allegations put to Penney is that he had asked for sections to be removed from a report by a member of the Australian CSIRO (Commonwealth Scientific and Industrial Research Organization) expressing concern over radiation levels from the British tests, in particular the BUFFALO series. Lord Penney was said to have seen the report as "alarmist pessimism" and scientifically unreliable as well; even after the report had been modified, publication was denied. Penney told the inquiry that he did not remember asking for sections of a report to be removed, but conceded that such a report from a man of reputation would have caused an almighty row. He agreed that if the report could have been upheld scientifically, it might have jeopardized the completion of the test programme.

Despite evidence that Australians at the test sites felt they were not consulted sufficiently, Penney said that they played a role in deciding whether or not to fire particular weapons. He said that the only time when the Australians demurred about a test was when 15 parliamentarians were going to be present to see the shot.

At Monday's sitting it was suggested that scientists working on the tests became so involved in the science that they failed to consider the implications of their work. Penney denied being carried away by the scientific beauty of the programme; "By God, I wish I could have got out and gone back to university. . .I thought we were going to have a nuclear war where the only hope I saw was that there should be a balance between East and West, but what I really wanted was to be a professor".

Susan Watts 